\title{
MULTIMODALITY OF THE CATEGORY EMOTIONS IN ART DISCOURSE: A FRACTAL SEMIOTICS PERSPECTIVE
}

\section{Iu.Iu. Shamaieva, PhD (Kharkiv)}

This article focuses on revealing the ontological peculiarities of the multimodal nature of the verbally represented category EMOTIONS in the ecology of art discourse. On the grounds of philosophy of emotion, psychology of art, cognitive theories of emotion and B. Mandelbrot's theory of fractals to complement the linguocognitive, cognitivediscursive and semiotics approaches, we elaborate an integrative evidence framework of the fractality of the category EMOTIONS in the circumflex of its conceptual components JOY, SADNESS, INTEREST, SURPRISE, ANGER, FEAR, DISGUST as natural fractals, actualized in modern art discourse in matrices of their conceptual features EXPERIENCE STIMULUS, APPRAISAL, EMERGENCE TIME, DIRECTION. A special emphasis has been laid on both the essence of art discourse, implying discourses on art and art as discourse, being an environment of conceptualizing and verbalizing aesthetic emotions, and on the role of the cognitive mechanisms of metaphors and metonymies in multimodal objectivizations of the category EMOTIONS fractals in discourses of visual arts and music (installations and tone painting). The relation between emotion, cognition, semiotics, art and language has been specified. As a result of the analysis based on the core multimodal research concepts of modes, semiotic resource, modal affordance and intersemiotic relations we have found out that verbalized category EMOTIONS conceptual ingredients are anchored in art perception, acquiring their fractal representation in clusters of modalities. The latter comprise the alethic, deontic, axiological, temporal, spatial, epistemic ones, getting recursively realized verbally, visually, aurally, linked with synesthesia, including chromesthesia, ideasthesia, spatial sequence, triggered by conceptualized and verbalized feeling experience response. With this work we demonstrate the value of fractal semiotics approach as a heuristic device to study multimodal categories.

Key words: art discourse, category, emotion, fractal semiotics, multimodality.

Шамаєва Ю.Ю. Мультимодальність категорії EMOTIONS в дискурсі мистецтва: вимір фрактальної семіотики. Стаття присвячена виявленню онтологічної специфіки мультимодальної природи вербально репрезентованої категорії EMOTIONS в екології дискурсу мистецтва. На теоретико-методологічній базі лінгвокогнітології, когнітивної дискурсології та семіотики, філософії емоцій, психології мистецтва, когнітивних теорій емоцій та теорії фракталів Б. Мандельброта розроблено інтегративний підхід до експлікації фрактальності категорії EMOTIONS у сукупності ї̈ концептуальних складників JOY, SADNESS, INTEREST, SURPRISE, ANGER, FEAR, DISGUST як природних фракталів, актуалізованих у сучасному дискурсі мистецтва у єдності їхніх концептуальних характеристик СТИМУЛ ЧУТТЄВОГО ДОСВІДУ, ОЦІКА, ЧАС ВИНИКНЕННЯ, НАПРЯМ. Особливий акцент зроблено як на поясненні сутності дискурсу мистецтва, що охоплює мистецтво як дискурс та дискурс про мистецтво у функції лінгвокогнітивного середовища емоцій, так і на ролі когнітивних механізмів метафоризації та метонімізації у мультимодальній об’єктивації фракталів категорії EMOTIONS в дискурсах образотворчого мистецтва та музики (інсталяції та тональний живопис у нашому випадку). Обгрунтовано зв'язок між емоцією, когніцією, семіотикою, мистецтвом та мовою. В результат аналізу, що базується на таких поняттях дослідження мультимодальності, як модальність, семіотичний ресурс, афорданс, інтерсеміотичні зв'язки, було виявлено, що концептуальні складники вербалізованої категорії EMOTIONS $є$ укоріненими у сприйнятті мистецтва, набуваючи характеристик фракталів у множинності модальностей, які включають як наративні алетичну, деонтичну, аксіологічну, темпоральну, просторову, епістемічну, так і рекурсивні вербальну, візуальну, аудіальну. Останні $\epsilon$ синестетично детермінованими 3 ознаками хроместезії, ідеастезії, активуючись концептуалізованими та вербалізованими чуттєво-екперієнціальними реакціями.

Ключові слова: дискурс мистецтва, емоція, категорія, мультимодальність, фрактальна семіотика.

Шамаева Ю.Ю. Мультимодальность категории ЕMOTIONS в дискурсе искусства: аспект фрактальной семиотики. Статья посвящена выявлению онтологической специфики мультимодальной

(C) Shamaieva Iu.Iu., 2018 
природы вербально репрезентированной категории EMOTIONS в экологии дискурса искусства. На теоретикометодологической базе лингвокогнитологии, когнитивной дискурсологии и семиотики, философии эмоций, психологии искусства, когнитивных теорий эмоций и теории фракталов Б. Мандельброта разработан интегративный подход к экспликации фрактальности категории EMOTIONS в совокупности ее концептуальных составляющих JOY, SADNESS, INTEREST, SURPRISE, ANGER, FEAR, DISGUST как естественных фракталов, актуализированных в современном дискурсе искусства в единстве их концептуальных характеристик СТИМУЛ чУВСТВЕННОГО ОПЫТА, ОЦЕНКА, ВРЕМЯ ВОЗНИКНОВЕНИЯ, НАПРАВЛЕНИЕ. Особый акценТ сделан как на объяснении сути дискурса искусства, так и на роли когнитивных механизмов метафоризации и метонимизации в мультимодальной объективации фракталов категории EMOTIONS в дискурсах изобразительного искусства и музыки (инсталляция и тональная живопись). Обоснована взаимосвязь между эмоцией, когницией, семиотикой, искусством и языком. В результате анализа, базирующегося на таких понятиях исследования мультимодальности, как модальность, семиотический ресурс, аффорданс, интерсемиотические связи, выявлено, что концептуальные составляющие категории EMOTIONS укоренены в восприятии искусства, приобретая характеристики фракталов в множественности модальностей, включая как алетическую, деонтическую, аксиологическую, темпоральную, пространственную, эпистемическую, так и рекурсивные вербальную, визуальную, аудиальную. Последние синестетически детерминированы, обладая признаками идеастезии и хроместезии, активируясь чувственными реакциями экспериенцера.

Ключевые слова: дискурс искусства, категория, мультимодальность, фрактальная семиотика, эмоция.

\section{Introduction}

Cognitive and emotional responses to art have long been a controversial subject of scientific debate, but only quite recently have they become an actual anthropocentric focus of extensive research in affective science, cognitive psychology, and psychology of art, cognitive linguistics, discourse studies and semiotics $[1 ; 2 ; 4 ; 5 ; 13 ; 23]$. This explicates the $\mathrm{t} \mathrm{i} \mathrm{m}$ e $1 \mathrm{i} \mathrm{n}$ e s s of the present work, a imed at revealing the fractal semiosis multimodality of the category EMOTIONS, actualized in art discourse, especially taking into account the current need for coherent transdisciplinary approaches to studying aesthetic emotions (S. Gallagher, P. Goldie, N.A. Krasavskij, H. Scott, V.I. Shahovskij, G. Sonesson), whose meaning "cuts between and across disciplines, mending the gap between science and humanities" [37, p. 18], their concepts and language of representational creation.

For that matter, pursuing the line of realizing my set objectives to reach the above aim, first, within the m e t h o d o 1 o g i c a 1 framework of cognitive linguistics, fractal semiotics by B. Mandelbrot and cognitive theories of emotion and art (G. Clore, J. Dilenno, J. Gibson, P.N. Johnson-Laird,
D. Matravers, K. Oatley, J. Palmer, S. Schachter, J.E. Singer and others) I concisely substantiate the multimodal nature of the category EMOTIONS, concentrating on fractal semiotics peculiarities of its ontology in art, which explicates the n o v e $1 \mathrm{t} y$ of the work, and on the specificity of art discourse as our research factual $\mathrm{m}$ a $\mathrm{t}$ e $\mathrm{r}$ i a 1 (emotion evoking objects of visual art, music pieces, the corresponding contemporary art criticism and academic articles analyzed).

Second, on the above theoretical grounds I examine how this categorial multimodality fractally functions in the ecology of art discourse, specifically in discourses of visual art (installations) and music (tone painting), with a special emphasis on the cognitive mechanisms of metaphorization and metonymization as both representants of the core categorial-conceptual characteristics EXPERIENCE STIMULUS, APPRAISAL, EMERGENCE TIME, DIRECTION and trigger tools of actualizing various synesthetic experience creating modalities of both narrative and non-narrative nature.

I conclude with summarizing the key points of the present research fragment as methodological implications for further exploration concerning the verbalized category EMOTIONS in art discourse. 
2. Category EMOTIONS as a multimodal entity in the discourse ecology of art: a fractal semiotics aspect

2.1. Fractal semiotics as a multimodal ontology of the category EMOTIONS in art discourse

Currently there are lots of intense debates as for definitions of emotions, their classifications, ways of studying them, which makes the field seem rather confusing. Cognitive approaches offer a clarifying perspective, focusing on causes of emotions, their effects [24], mechanisms of their conceptualization, verbalization, and communication. At present most of definitions of emotions encountered in psychological and linguistic literature assume emotions and feelings as their experiential parts to be attribute processes parallel to other psychological and physiological processes of a cognitive, motivational or conative nature $[21 ; 28]$, a particular, elemental kind of intelligence, "an important and integral part of the functional system of human behavior" [33, p. 65], functioning as a "multicomponential dynamics that doesn't necessarily cohere in fixed packages and continuously change" [25, p. 244]. Emotions get conceptualized, acquiring, according to the results of our previous research stage, their core conceptual features EXPERIENCE STIMULUS, APPRAISAL, EMERGENCE TIME, DIRECTION [31], which experimentally prove to be categorial for the concepts of basic emotions JOY, SADNESS, INTEREST, SURPRISE, ANGER, FEAR, DISGUST [32, p. 9].

Aesthetic experience has two outcomes, "aesthetic judgment and aesthetic emotion" [10, p. 9]. Since art experience is claimed to be one of the most powerful forms of eliciting and communicating emotions $[7 ; 23 ; 24]$, we regard it and its corresponding discourse as one of the most potent experience stimuli of emotions to be conceptualized, categorized and verbalized, determining their appraisal and direction conceptual characteristics. Since in the linguocognitive environment of art visual, aural, embodied, and spatial aspects of Homo Sentiens' emotions, their concepts, forming the category EMOTIONS, and their discourse actualizations, generating other types of emotional experience to be conceptualized, constantly interact in various dimensions we consider the category EMOTIONS, constituting the $\mathrm{subject}$ matter of our work, to be an ontologically multimodal fractal entity with its unique fractal semiotics that continually expand the space of human aesthetic experiences on the basis of recursive cooperation among emotion, cognition, semiotics, language, and culture $[6 ; 12 ; 37]$.

Following J. Bezemer [11], the above status can be substantiated by the following theoretical underpinning assumptions that directly refer to conceptual components of the category under consideration. First, fractal multimodality assumes that representation and communication always draw on a multiplicity of modes that contribute to meaning sustainability, which can be observed in the way the category EMOTIONS functions in the multitude of its conceptual art realizations (visual, spoken, aural, gestural). Second, fractal multimodality presupposes that resources are socially shaped over time, which is the case with emotions and their linguocognitive representations in art discourse, articulating socioculturally determined affective meanings through the choice of a cognitive semiotics mode. Finally, meaning of emotion and verbalizations of its conceptual representation is construed through selecting and configurating modes as outcomes of the linguocultural shaping through their use [36], with the significance of their interaction foregrounded [6], which is obvious in the realm of art concepts of the category EMOTIONS, objectivized in different art contexts. The above plausibly includes intersemiotically mapping semiotic resources of a number of emotion ontological modes, such as visual communication, color, texture, gesture, movement, sound, voice, music, to name a few, susceptible to their multifaceted verbal objectivization in discourse of art works, reviews and criticism.

Since empirical linguocognitive experience proves that meanings of verbal representations of emotions, even their nominations, simultaneously activate several domains that in their conceptual entirety make a matrix $[3$, c. 80$]$ and since the domain EMOTION perceptively rooted in affective systems [3, c. 79] belongs to basic domains as "cognitively irreducible representational spaces or fields of conceptual potential" [20, p.5], "directly tied to pre-conceptual gestalt embodied experience" $[15$, p. 439], we assume that concepts of emotions, intrinsically making the category EMOTIONS and 
representing it in a number of semiotic ways in art discourse, possess properties of fractals in terms of the theory of fractals by B. Mandelbrot. Understanding a fractal as "a shape or entity whose basic features reappear in different scales, defined by a recursive process that generates autosimilar structures, combining structural irregularity and consistency" [26, p. 374], we have found out that there is a close affinity between natural fractals, their semiotic ontology, concepts of emotions and their language representations in art discourse, which comprises several dimensions: structural autosimilarity, scalar relativity, irregularity, formal consistency, fractal dimension, expressed in the multimodality of the category EMOTIONS.

Taking into consideration the specificity of the subject matter cognitive fractal semiosis, I have developed a methodological triangulation whose goal is to provide research interdisciplinarity within the respective field of inquiry through integrating various methods derived from three perspectives (suggested by J. Zlatev [37]), presupposing the corresponding methods, in one project: 1) the subjective perspective, involving methods of conceptual analysis (including focusing on conceptual metaphors and metonymies as conceptual representation fractals of the category researched, evoking various modes of synesthesia), phenomenological analysis, systematic intuitions (applied to reveal perceptions, mental imagery in terms of secondary conceptualizations and nominations); 2) intersubjective perspective, relying on empathy and imaginative projection (to uncover peculiarities of social/art interactions); 3) objective perspective, implying observation and modelling (to study ontological features of the category EMOTIONS in art discourse).

Thus, the category EMOTIONS actualized in art discourse has been proved to be a fractal multimodal entity whose research presupposes using methods of cognitive linguistics, cognitive fractal semiotics and discourse analysis.

\subsection{Multimodality of the category}

EMOTIONS actualized in art discourse: a fractal semiotics approach

This part of the article presents fragments of my linguocognitive semiotic analysis of the installation artwork of London Design Biennale 2018 themed
"Emotional States" and the music genre of tone painting (also known as word painting). The attention focus is on actual ontological fractal semiotics peculiarities of the multimodality of the category EMOTIONS, actualized in these types of art discourse, with an emphasis on the role of cognitive mechanisms of metaphor and metonymy as triggers of various modes of synesthesia, substantiating the fractality of the category examined. Here it has to be pointed out that from this multimodal study perspective, art discourse is both emotion arousing works of art and relevant art criticism as dynamic art history about recent objects, involving judgment without assuming anything, a flow of ideas, conversations, and attitudes that make up the contemporary art eco-system: making, writing, exhibiting, believing, appreciating and so on [35]. Thus, discovering heterogeneous modalities of the fractal categorial organism EMOTIONS draws upon the core multimodal research concepts of modes, semiotic resource, modal affordance (the concept, developed by J. Gibson, which "strengthens the idea that individual and the environment are interconnected and cannot be analyzed separately" [9, p. 364]), and intersemiotic relations.

According to A. Damasio [14], an emotion and its concept as a building block of the category EMOTIONS are dispositive images (the so-called dispositional representation that holds the rules to reconstruct perceptual images multimodally through human senses, their mental objectivizations and verbalizations) that affects the body internal state, not being the perception of it (the perception is the feeling not the emotion itself). Moreover, "every emotion, every burst of passion, every exercise of will, is like cognition [10, p. 144]. Indeed, emotions and art are intimately related $[8 ; 14 ; 34 ; 35 ; 37]$, which results in five-part emotional experience: the art addressee's preexpectations and self-image; cognitive mastery and introduction of discrepancy, concerning the work and understanding; secondary control and escape, presupposing higher-order cognitive involvement and mentally withdrawing from the work to resolve it emotionally; meta-cognitive emotional reassessment, which implies self-awareness and emotion-awareness through a work of art with subsequently editing one's own self-image; aesthetic outcome in the format of a new emotional response and new mastery of the artwork [21;28]. The above elements of aesthetic 
experience obtain their conceptual and verbal objectivization through cognitive operations of metaphorization and metonymization in art discourse both of installations as a domain of visual art and tone painting in music.

Let us have a glimpse of our analysis concerning the realization of the fractal multimodality of the category EMOTIONS in the discourse of the Australian installation artwork "Love" (a type of art that belongs to visual semiotics as it is based on one of the senses - vision [26], naturally including any visually perceived information) as part of London Design Biennale 2018 "Emotional States" (www.londondesignbiennale.com/emotional-states), representing over 40 countries from six continents and "examining the full spectrum of emotional experiences, from anger to joy, sadness to disgust" (following Director of the event Dr Ch. Turner, who continues: "The installations propose radical and provocative ideas and investigate the important relationship between design, strong emotional responses, and real social needs"). Both its figural composition (the visual mode fractal) with its title (the verbal mode fractal) and art criticism concerning "Love" allow us to reveal its unique semiotic code of verbally actualized conceptual metaphors and metonymies, whose co-occurrence influence the emotional interpretation of the artwork in a cluster of other core modalities of emotion ontology, such as aletic (mandatory, possible, impossible), deontic (assigned, allowed, forbidden), axiological, epistemic (knowledge, opinion, behavior), temporal and spatial (here, there, nowhere) .

For instance, visitors "get embraced by an enlarged rainbow color wash" made from 150 strands of fiber optic light, each one of a different color. In this way its designer F. Talbot "communicates the feeling of love and the emotion of openness and celebrates the country's newlypassed legislation that makes same-sex marriage legal" (archipanic.com). The enlargement seems deliberate, probably suggesting the visual manifestation of the conceptual metaphor MORE OF FORM IS MORE OF CONTENT [19, p.127] and SIGNIFICANT/IMPORTANT IS BIG (implying the revolutionary nature of the social breakthrough in Australia). The size of the installation is magnified, and viewers have to look up, which may manifest the metaphorical reasoning BEING SUBJECT TO CONTROL [19, p. 15] of love. In fact, Flynn himself says: "I wanted to explore a positive emotion, and represent a positive Australia. Now in the air there is a new tangible feeling of what love means (flynntalbot.com). Evoking the synesthetic associations, in particular, those of chromesthesia, ideasthesia, spatial sequence, triggered by conceptualized and verbalized feeling experience response, the concept LOVE, actualized multimodally, proves to be of a fractal nature, emerging and acquiring multimodal reinforcement through light, color, scaling, an open space (AIR): "I see love as a full spectrum emotion and have used the full spectrum of color" (flynntalbot.com).

At the same time, conceptual metaphor and metonymy make a strong conceptual bond in the artwork discourse studied, since the metonymic interpretation offers the contextual foundation via which metaphors can be construed $[16 ; 18]$. This gets especially conspicuous in the interpretation of the missing heart lines on the surface under the rainbow, which can be conceptualized as missing the true source of love. The conceptual contiguity seems crucial in the process of construing the meaning of the nomination, verbally representing the examined conceptual element of the category EMOTIONS because the heart inspires the metonymy the CONTAINER FOR CONTAINED. By entailment, the heartless or the damaged-hearted can evoke the opposite meaning, such as LACK/MISSING PARTS OF HEART FOR LACK OF TRUE LOVE. Besides, the CONTAINER image-schema [19] also contributes to the fractal semiotics representation of the culturally determined conceptual emotion meaning of the installation. In Western linguoculture, the heart is regarded as an organ with which emotions are associated, and love in particular, and this conceptualized and discursively actualized part of the body metonymically evokes the corresponding feeling. The title of the installation can also serve as the so-called anchorage (R. Barthes' term) because it makes interpretations of emotions more specific. Therefore, it can be assumed that the category EMOTIONS is actualized in all the above modalities, rooted in blended art perception, and can be analyzed as a fractal model in a dynamic creation of its 
emotional conceptual components (LOVE being one of them, in our case).

Another art ecology of the category EMOTIONS, frequently going together with creating installations to enhance emotional impacts designed, that we are going to briefly consider in this work is music. Music contemplation can trigger multiple emotions, being a metaphor and metonymy of emotions in itself [22]. There is much evidence for a stable connection of music, cognition, emotion $[8 ; 25 ; 27]$ with various synesthetic implications [28;34]. Music is a product of mind [8;29], and its physics of the cosmos vibrational elements of frequency, form, amplitude, duration are not really music until they are neurologically transformed, conceptualized, emotionally interpreted by the brain, multimodally categorized, acquiring characteristics of timbre, loudness, time (the tonal frame), evoking new emotional intersemiotic experiences [27]. Thus, conceptual elements of the category EMOTIONS turn out to be anchored in music perception, revealing its various modalities, like in the case with the art of installations.

It is especially clear when we focus on tone painting as the musical technique when music reflects the literal meaning of a song's (verbal vocalization) lyrics. This type of the category EMOTIONS ontology goes back to Gregorian chants (https:// m.youtube.com/watch? $\mathrm{v}=$ sxsNgzSNSFo), whose authorship is generally credited to the Benedictine monk Paulus Diaconus. They can also be called contemporary art since they are fruitfully used in lots of marginal or hybrid arts nowadays, including visual art discussed above. There concepts of emotions are verbalized by means of nominations that express both emotion and theological meanings [17]. In this connection, it is worth pointing out that the eighthcentury treatise "De octo tonis" ("On the eight modes") even compares musical tones to the letters of speech (http://www.chmtl.indiana.edu/tml $/ 6^{\text {th }}-8^{\text {th }} /$ ALCMUS TEXT.html), and a treatise transmitted in the ninthcentury manuscript of the "Carolingian" Tonary of Metz compares the eight modes to the eight parts of speech in Latin grammar. To illustrate, according to the results of a melodic-semiotic functional analysis [29], the pattern fa-mi-sol-la metaphorically, on the synesthetic basis of ideasthesia and spatial sequence, seem to represent the sufferings and death of Christ with His resurrection into glory, where fa-mi signifies deprecation, sol is the note of Resurrection, and la is above the resurrection [30], which through conceptual metaphors, metonymies (when vocalization of $l a$ mirrors angels' voices and Heavens) and synesthetic associations (the higher the pitch, the lighter and brighter everything gets [29]). Besides, every time the combination fa-mi-sol-la placed on words from the Biblical Latin text emerges (e.g. FAtum laxis MIra gestorum FAmili tuorum SOLve pollute LAbii reatum) it is assigned to be performed on et libera (freely), which "for Christians signifies that Christ liberates people from sin through His death and resurrection" [29, p. 157], following Arsis and Thesis of every word with lifts of tonic accents, which in Latin means movement of life and repose [17].

Modern examples of tone painting as a metaphorical and metonymical tool of discursively actualizing concepts of emotions within the fractal framework of the category EMOTIONS are very numerous. For instance, "Hallelujah" by L. Cohen (https://m.youtube.com/watch? $v=c c G z-l i$ rgM), where the words "It goes like this: the fourth, the fifth, the minor fall and the major lift, the baffled king composing hallelujah" express the movement of the keys, mentioned in the analysis of Gregorian chants, and the tone progression; "Toxicity" by "System of a Down"

(https://www.youtube.com/watch? $\mathrm{v}=\mathrm{iywaBOMvYLI)}$ with its octave descends and returns up at a slower tempo, showing the global scale of what is happening to this world, at the words: "How do you own disorder?"; in the first chorus in "Despacito" by L. Fonsi

(https://www.youtube.com/watch?v=kJQP7kiw5Fk), where the music is slowed at the word despacito (slowly); "Bohemian Rhapsody" by F. Mercury (https://www.youtube.com/watch?v=fJ9rUzIMcZQ), where in the phrase "escape from reality", for example, escape is sung at the highest note and reality is much lower, to name just a few. This observation proves that the fractal multimodality of the category EMOTIONS in this domain of art discourse has already become a natural aspect of music perception and of the way concepts of emotions are semiotically represented.

\section{Conclusions}

The theoretical perspectives of cognitive linguistics, fractal semiotics, theory of multimodality, cognitive theories of emotions and art surveyed, the present work has laid out a 
tentative comprehensive approach to studying the category EMOTIONS as a multimodal complex result of fractal semiosis of emotions, their concepts and verbal representations in discourses of visual arts (installations) and music (tone painting). My main findings are based on the revelation and recognition of the multimodal nature of the category researched, actualized in semiotic fractals of metaphors, metonymies of emotions and their intersemiotic relations on a continuum of conceptual complexity. There turn out to be at least four crucial implications in this connection: 1) conceptual ingredients of the verbalized category EMOTIONS are anchored in art perception; 2) they acquire their fractal representation in clusters of modalities, comprising the alethic, deontic, axiological, temporal, spatial, epistemic ones, recursively realized verbally, visually, aurally, in close association with synesthesia, triggered by conceptualized and verbalized feeling experience response; 3) the interaction of metaphor as a representation of emotional concepts with other cognitive operations lets us expand the range of possible meaning construction processes, including synesthesia in its chromesthetic, ideasthetic, and spatial sequence dimensions; 4) metaphormetonymy interactions in multimodal ontologies are much more complex that the volume of inference involved in decoding a single metaphor or metonymy in just verbal environment, creating more associations and conceptual fields, facilitating the process of understanding emotions and the content architectonics of the category EMOTIONS.

All the above pre-determines the pers pective of our research, which is a more in-depth analysis of the fractal semiotics multimodality of the category EMOTION in multiple dimensions of art discourse, aimed at building a comprehensive interdisciplinary methodology of studying multimodal categories within the framework of cognitive linguistics, cognitive fractal semiotics, and linguoculturology with a special focus on mode hierarchies, modelling the category EMOTIONS as a fractal semiotic system to discover a wide range of applications for multimodal investigation in fields like media, advertisement, entertainment, education, marketing, medicine and psychology of positivity.

\section{LITERATURE}

1. Болдырев методологические

H.H. Теоретические и аспекты языковой интерпретации // Интерпретация мира в языке. Тамбов: Изд. дом ТГУ им. Г.Р. Державина, 2017. С. 19-81. 2. Буянова Л.Ю. Эмотивность и эмоциогенность языка: механизмы экспликации и концептуализации. М.: ФЛИНТА, 2016. 232 с. 3. Бондаренко Е.В., Мартынюк А.П., Фролова И.Е., Шевченко И.С. Как нарисовать портрет птицы: методология когнитивно-коммуникативного анализа языка. Х.: ХНУ им. В.Н. Каразина, 2017. 246 с. 4. Мечковская Н.Б. Семиотика: Язык. Природа. Культура. М.: Академия, 2004. 432 с. 5. Розин В. Семиотические исследования. СПб: Университетская книга, 2016. 256 с. 6. Тарасенко В.В. Фрактальная семиотика: «слепые пятна», перипетии и узнавания. М.: ЛИБРОКОМ, 2009. 232 с. 7. Чертов Л.Ф. Знаковая призма: статьи по общей и пространственной семиотике. М.: Языки славянской культуры, 2014. 320 с. 8. Barbiere J., Vidal A., Zellner D. The color of music: correspondence through emotion // Empirical studies oft he arts. Vol 25 (2). 2007. P. 193-208. 9. Batista S. Emotional branding: emotions and feelings aroused by the design of the olfactory experience of consumption according to the ecosystem approach to communication // Systems and design: beyond processes and thinking. 2016. 16. P. 361-376. 10. Beeson R. Peirce on the passions: the role of instinct, emotion, and sentiment in inquiry and action // American studies common. Graduate theses and dissertations. 2008. Режим доступу: http:// scholarcommons.usf.edu/etd. 11. Bezemer J., Mavers D. Multimodal transcription as academic practice // International journal of social research methodology. 2011. Vol.14, \# 3. P. 191-206. 12. Consoli G. A cognitive theory of the aesthetic experience // Contemporary aesthetics. 2012. Vol. 10. Режим доступу: http:// hdl.handle.net/2027/spo.7523862.0010.006.

13. Dąbrowska D. A multimodal perspective on metaphors and metonymies in art: a case study of the artwork Agora by Magdalena Abakanowicz // Crossroads. A journal of English Studies. 2016. 10. P. 4-12. 14. Damasio A. Descarte's error. Emotion, reason, and human brain. NY: Avon Books, 1995. 302 p. 15. Gärdenfors P., L'hndorf S. What is a domain? Dimensional structures versus meronomic relations // Cognitive linguistics. 2013. 24 (3). P. 437-456. 16. Geeraerts D. The interaction of metaphor and metonymy in composite expressions // Metaphor and metonymy in comparison and contrast. Berlin: Moutin 
de Gruyter, 2002. P. 435-465. 17. Heckenlively L.F. The fundamentals of Gregorian chant. Tournai: Society of St John Evangelist, 1978. 308 p. 18. Konečni V. Paintings and emotion: a nonemotivist reevaluation // Theoria 3. 2015. 58. P. 5-18. 19. Lakoff G., Johnson M. Metaphors we live by. Chicago: The University of Chicago Press, 1980. 242 p. 20. Langacker R. W. An introduction to cognitive grammar // Cognitive science. 1986. 10. P. 1-40. 21. Leander K., Aziz S., Botzakis S., Ehret Ch., Landry D., Rowsell J. Readings and experiences of multimodality // Literacy research: theory, method, and practice. 2017. Vol. 66. P. 95-116. 22. Miu A., Pitur S. Aesthetic emotions across arts: a comparison between painting and music // Frontiers in psychology. 2015. 6. P. 195-198. 23. Noy P., Noy-Sharav D. Art and emotions // International journal of applied psychoanalytic studies. 2013. \# 10 (2). P. 100-107. 24. Oatley K., Johnson-Laird P.N. Cognitive approaches to emotions // Trends in cognitive sciences. 2013. Vol.XXX. P. 1-7. 25. Ochsner K.N., Gross J.J. The cognitive control of emotion // Trends in cognitive sciences. 2014. \# 9. P. 242-249. 26. Pareyon G. Fractal theory and language: the form of macrolinguistics // Form and symmetry: art and science. 2007. \# 15. P. 374-377. 27. Parker O. Music cognition: the relationship of psychology and music // Perception and cognition of music. 2014. Р. 308-314. Режим доступу:

http://www.escom.org/proceedings/ICMPC2014/po ster3/Parker.htm. 28. Pelovski M., Fuminori A. A model of art perception, evaluation and emotion in transformative aesthetic experience // New ideas in psychology. 2011. \# 29 (2). P. 80-97. 29. Porterfield R. Melodic function and modal process in Gregorian chant: diss ...PhD. NYC: City University of NYC, 2014. 362 p. 30. Saulnier D. Gregorian chant: a guide to the history and theory. Solesmes: Paraclete Press, 2010. 128 p. 31. Shamaieva Yu. Nominations of emotions as a key to their categorization // Cognitive studies of language. Cognitive linguistics in the anthropocentric paradigm: International Congress on Cognitive Linguistics, 20-22 Sept., 2017: Proc. Vol. XXX. Moscow - Tambov - Belgorod, 2017. P. 199-202. 32. Shamaieva Iu. Iu. Category EMOTIONS as a multimodal linguo-cognitive matrix of Homo Sentiens discourse ecology // Вісник ХНУ ім. В.Н. Каразіна. Сер. «Романогерманська філологія. Методика викладання іноземних мов». 2017. № 86. Р. 6-14. 33. Shevchenko I. Transformations of expressives through history in cognitive-communicative perspective // Вісник ХНУ ім. В.Н. Каразіна. Сер. «Романо-германська філологія.
Методика викладання іноземних мов». 2015. № 1155. P. 64-68. 34. Silvia P. Emotional responses to art: from collation and arousal to cognition and emotion // Review of general psychology. 2005. Режим доступу: http://www.researchgate.net/profile/Paul_Silvia/publication /232468613. 35. Skinner D. Throwing stones in glass houses: on criticism, art history and critical discourse // Criticality. 2014. Режим доступу: http:// artjewelryforum.org/articles-series/throwing-stones-inglass-houses-on-criticism-art-history-and-critical-

discourse 36. Sonesson G. Semiotics of Photography on tracing the index. Pictorial meanings in the society of information. Georgetown: Lund University Press, 2014. 142 p. 37. Zlatev J. Cognitive semiotics: an emerging field for the transdisciplinary study of meaning // The public journal of semiotics. 2012. IV (1). P. 2-24.

\section{REFERENCES}

Boldyrev, N.N. (2017).Teoreticheskie i metodologicheskie aspekty jazykovoj interpretacii [Theoretical and methodological aspects of language interpretation]. In: Interpretacija mira v jazyke [World interpretation in language]. Tambov: Izd. dom TGU im. G.R. Derzhavina, 19-81.

Bondarenko, E.V., Martynjuk, A.P., Frolova, I.E., and Shevchenko, I.S. (2017). Kak narisovat' portret pticy: metodologija kognitivno-kommunikativnogo analiza jazyka [How to draw a portrait of a bird: methodology of a cognitive-communicative analysis of language]. H.: HNU im. V.N. Karazina Publ.

Bujanova, L.Ju. (2016). Jemotivnost' $i$ jemociogennost' jazyka: mehanizmy jeksplikacii $i$ konceptualizacii [Emotivity and emotional potential of a language; mechanisms of explication and conceptualization]. M.: FLINTA

Mechkovskaja, N.B. (2004). Semiotika: Jazyk. Priroda. Kul'tura [Semiotics. Language. Nature. Culture]. M.: Akademija.

Rozin, V. (2016). Semioticheskie issledovanija [Semiotic research]. SPb: Universitetskaja kniga Publ.

Tarasenko, V.V. (2009). Fraktal'naja semiotika: «slepye pjatna», peripetii $i$ uznavanija [Fractal semiotics: "blind spots", peripeties and recognitions]. M.: LIBROKOM Publ.

Chertov, L.F. (2014). Znakovaja prizma: stat'i po obshhej $i$ prostranstvennoj semiotike [Sign prism: articles on general and spatial semiotics]. M.: Jazyki slavjanskoj kul'tury Publ. 
Barbiere, J., Vidal A., Zellner, D. (2007). The color of music: correspondence through emotion. Empirical studies of the arts, 25 (2), 193-208.

Batista, S. (2016). Emotional branding: emotions and feelings aroused by the design of the olfactory experience of consumption according to the ecosystem approach to communication. Systems and design: beyond processes and thinking, 16, 361-376.

Beeson, R. (2008). Peirce on the passions: the role of instinct, emotion, and sentiment in inquiry and action. In: M. Grown (ed.). American studies common. Graduate theses and dissertations. Available at: http:// scholarcommons.usf.edu/etd.

Bezemer, J., Mavers, D. (2011). Multimodal transcription as academic practice. International journal of social research methodology, 14 (3), 191206.

Consoli, G. (2012). A cognitive theory of the aesthetic experience. Contemporary aesthetics, 10 Available at: http:// hdl.handle.net/2027/spo. 7523862.0010 .006 .

Dąbrowska, D. (2016). A multimodal perspective on metaphors and metonymies in art: a case study of the artwork Agora by Magdalena Abakanowicz. Crossroads. A journal of English Studies, 10, 4-12.

Damasio, A. (1995). Descarte's error. Emotion, reason, and human brain. NY: Avon Books.

Gärdenfors, P., and Löhndorf S. (2013). What is a domain? Dimensional structures versus meronomic relations. Cognitive linguistics, 24 (3), 437-456.

Geeraerts, D. (2002). The interaction of metaphor and metonymy in composite expressions. In: Metaphor and metonymy in comparison and contrast. Berlin: Moutin de Gruyter, pp. 435-465.

Heckenlively, L. (1978). The fundamentals of Gregorian chant. Tournai: Society of St John Evangelist.

Konečni, V. (2015). Paintings and emotion: a nonemotivist reevaluation. Theoria 3, 58, 5-18.

Lakoff, G., and Johnson M. (1980). Metaphors we live by. Chicago: The University of Chicago Press.

Langacker, R. W. (1986). An introduction to cognitive grammar. Cognitive science, 10, 1-40.

Leander, K., Aziz, S., Botzakis, S., Ehret, Ch., Landry, D., and Rowsell, J. (2017). Readings and experiences of multimodality. Literacy research: theory, method, and practice, 66, 95-116.

Miu, A., and Pitur, S. (2015). Aesthetic emotions across arts: a comparison between painting and music. Frontiers in psychology, 6, 195-198.
Noy, P., and Noy-Sharav, D. (2013). Art and emotions. International journal of applied psychoanalytic studies, 10 (2), 100-107.

Oatley, K., and Johnson-Laird P.N. (2013). Cognitive approaches to emotions. Trends in cognitive sciences, $X X X, 1-7$.

Ochsner, K., and Gross, J. (2014). The cognitive control of emotion. Trends in cognitive sciences, 9, 242-249. Pareyon, G. (2007). Fractal theory and language: the form of macrolinguistics. Form and symmetry: art and science, 15, 374-377.

Parker, O. (2014). Music cognition: the relationship of psychology and music. Perception and cognition of music. Available at: http://www.escom.org/proceedings/ICMPC2014/poster 3/Parker.htm.

Pelovski, M., and Fuminori, A. (2011). A model of art perception, evaluation and emotion in transformative aesthetic experience. New ideas in psychology, 29 (2), 80-97.

Porterfield, R. (2014). Melodic function and modal process in Gregorian chant: diss ...PhD. NYC: City University of NYC.

Saulnier, D. (2010). Gregorian chant: a guide to the history and theory. Solesmes: Paraclete Press.

Shamaieva, Yu. (2017). Nominations of emotions as a key to their categorization. In: Cognitive studies of language. Cognitive linguistics in the anthropocentric paradigm: International Congress on Cognitive Linguistics, 20-22 Sept., 2017: Proc. Vol. XXX. Moscow, Tambov, Belgorod, pp. 199-202.

Shamaieva, Iu. (2017). Category EMOTIONS as a multimodal linguo-cognitive matrix of Homo Sentiens discourse ecology. Visnyk Kharkiv. nats. un-tu im.V.N.Karazina. - V.N. Karazin Kharkiv National University Messenger, 86, 6-14.

Shevchenko, I. (2015). Transformations of expressives through history in cognitivecommunicative perspective. Visnyk Kharkiv. nats. untu im.V.N.Karazina. - V.N. Karazin Kharkiv National University Messenger, 1155, 64-68.

Silvia, P. (2005). Emotional responses to art: from collation and arousal to cognition and emotion. Review of general psychology. Available at: http:// www.researchgate.net/profile/Paul_Silvia/_publication/ 232468613

Skinner, D. (2014). Throwing stones in glass houses: on criticism, art history and critical discourse. Criticality. Available at: http:// artjewelryforum.org/articles-series/throwing-stones-inglass-houses-on-criticism-art-history-and-criticaldiscourse 
Sonesson, G.(2014). Semiotics of Photography - on tracing the index. Pictorial meanings in the society of information. Georgetown: Lund University Press.
Zlatev, J. (2012). Cognitive semiotics: an emerging field for the transdisciplinary study of meaning. The public journal of semiotics, $I V(1), 2-24$.

Шамасва Юлія Юріївна - кандидат філологічних наук, доцент, доцент кафедри методики та практики викладання іноземних мов Харківського національного університету імені В.Н. Каразіна; еmail: yuliyashamayeva@gmail.com; SCHOLAR. GOOGLE: https://scholar.google.com.ua/ citations?hl=uk\&user=[z7iQZgAAAAJ\&view_op=list_works\&authuser=1; $\quad$ ORCID: https://orcid.org/ 0000-0001-7874-5510; RESEARCHGATE: https://www.researchgate.net/profile/Ulia_Shamaeva; LINKEDIN: linkedin.com/in/yuliya-shamaeva-1751057b 